\title{
A Selective Gas Chromatography-Selected Ion Monitoring Mass Spectrometry (GC-MS/SIM) Method to Determine Polychlorinated Biphenyls in Fuller's Earth
}

\author{
Melina Espanhol-Soares, ${ }^{\oplus *, a}$ Milady R. A. Silva, ${ }^{a}$ Rossano Gimenes ${ }^{a}$ and Flávio S. Silva ${ }^{a}$ \\ ${ }^{a}$ Instituto de Física e Química, Universidade Federal de Itajubá, 37500-903 Itajubá-MG, Brazil
}

\begin{abstract}
Polychlorinated biphenyls (PCBs) are carcinogenic to humans and can be found in Fuller's earth used for the regeneration of used transformer oil. This work describes a highly selective gas chromatographic-selected ion monitoring mass spectrometric method (GC-MS/SIM) for the simultaneous determination of three Aroclor PCB congener mixtures (1242, 1254, and 1260). The separation of the PCBs could be systematically varied by changing the temperature conditions of the chromatographic column. Methods were first selected from the literature, and the resolution of the PCBs was then optimized by adjusting $\mathrm{k}^{*}$ (effective retention), $\alpha$ (selectivity), and $\mathrm{N}$ (column efficiency), enabling the detection of 83 PCBs in 35 min. The extract of PCBs from Fuller's earth was obtained by ultrasonication (employing hexane and acetone as solvents) and cleanup with Florisil and was concentrated to about $500 \mu \mathrm{L}$. The ions analyzed in SIM mode were divided into groups according to the similarity $(\mathrm{m} / \mathrm{z})$ of the PCB fragmentation profiles. The limits of detection (LOD) and quantification (LOQ) were 0.19 and $0.64 \mu \mathrm{g} \mathrm{kg}^{-1}$, respectively. The method developed was used to determine the PCBs present in Fuller's earth provided by an electric power company. The mean total PCBs concentration was found $1.9 \mu \mathrm{g} \mathrm{kg}^{-1}$ in Fuller's earth.
\end{abstract}

Keywords: polychlorinated biphenyls, PCBs, optimization, GC-MS/SIM, Fuller's earth

\section{Introduction}

Polychlorinated biphenyls (PCBs) are compounds that generally consist of two phenyl groups with benzene rings that are bonded to chlorine atoms. ${ }^{1}$ The compounds have $\log \mathrm{K}_{\mathrm{ow}}$ (octanol-water partition coefficient) values in the region of 5-8, indicating a high degree of lipophilicity. ${ }^{2}$ PCBs can be found in dielectric and coolant fluids, for example in electrical apparatus, cutting fluids used for machining operations, carbon paper, and heat transfer fluids. ${ }^{3}$

The production of PCBs has been banned since the 1970s and 1980s. According to the Stockholm Convention, these substances are considered persistent organic pollutants (POPs) that can cause harm to the environment and human health. In order to control emissions of PCBs, all parties to the Stockholm Convention are obliged to stop using PCBs before 2025. ${ }^{4}$ In order to achieve this goal, companies need to decontaminate their equipment and implement waste management strategies. ${ }^{5}$

Fuller's earth is used for the regeneration of used transformer oil by adsorption of degradation products, so

*e-mail: melespanhol@yahoo.com.br this material can also retain the PCBs. These compounds are highly persistent environmental contaminants originating from the improper disposal and storage of old electrical equipment. ${ }^{6}$ In soils, PCBs may be present as mixtures, due to microbial degradation in the soil and other reactions that occur in biota. Screening for PCBs has been used to identify these mixtures in soil samples and other environmental matrices. ${ }^{7}$ The compounds can be extracted from soil using nonpolar solvents such as $n$-hexane, dichloromethane, or a hexane/acetone mixture. The procedures may include ultrasonication, Soxhlet extraction, or microwave assistance. Sample cleanup is performed using columns of Florisil or silica/alumina. ${ }^{89}$ Soxhlet extraction can be combined with other methodologies involving heating and pressure. ${ }^{10}$

The most useful techniques for the sensitive and selective determination of PCBs include gas chromatography (GC) with electron capture detection (ECD), as well as mass spectrometry (MS) detector. ${ }^{11}$ The EPA $8270,{ }^{12}$ ASTM D4059, ${ }^{13}$ and NBR $13882^{14}$ methods specify gas chromatography with ECD or MS detection for the quantification of PCBs.

Adequate screening methodologies are essential in order to detect substances potentially toxic to humans and the environment, considering the list compiled by 
the Stockholm Convention. ${ }^{15}$ The molecular structures of PCBs influence their toxicities to organisms. In particular, interaction of the flat molecule with two phenyl rings and the aryl hydrocarbon receptor leads to coplanar structures that can act more aggressively in organisms. ${ }^{16}$ Other factors that influence toxicity include the number of aromatic rings and their positions, as well as the number of chlorine atoms in the PCB molecule (World Health Organization (WHO)). ${ }^{17}$ The WHO has published a list of the PCBs and their toxic equivalency factors (TEFs). ${ }^{17}$

Central composite, simplex, and factorial designs, together with response surface methodology, can be used in chemometric methods for the optimization of chromatographic conditions and improvement of PCB separation efficiency. ${ }^{18,19}$ However, these procedures require large numbers of experiments, are expensive, and require some knowledge of statistical software. The separation of PCBs can be systematically varied by changing the experimental conditions. In this work, the separation of 83 PCBs determined by GC-MS in selected ion mode (SIM) was optimized using three chromatographic parameters: $\mathrm{k}^{*}$ (effective retention), $\alpha$ (selectivity), and $\mathrm{N}$ (column efficiency), which are directly related to the experimental conditions. ${ }^{20,21}$ The parameter $\mathrm{k}^{*}$ is the average retention factor for two compounds, $\mathrm{N}$ is the column plate number, and $\alpha$ is the separation factor $\left(\alpha=\mathrm{k}_{2} / \mathrm{k}{ }_{1}\right.$, where $\mathrm{k}{ }_{1}$ and $\mathrm{k}^{*}{ }_{2}$ are the values of $\mathrm{k}^{*}$ for compound 1 and compound 2 , respectively). Equation 1 is useful in method optimization, because it classifies the dozen or so experimental variables into three categories: effective retention $\left(\mathrm{k}^{*}\right)$, selectivity $(\alpha)$, and column efficiency $(\mathrm{N}){ }^{22}$ This simplifies the systematic variation of the conditions in order to achieve the desired separation. It is convenient to consider $\mathrm{k}^{*}, \mathrm{~N}$, and $\alpha$ as independent of each other, so that changes of each individual variable can be made without affecting the other two variables. ${ }^{21}$
$\mathrm{R}_{\mathrm{s}}=1 / 4(\alpha-1) \mathrm{N}^{1 / 2} \mathrm{k} * /\left(1+\mathrm{k}^{*}\right)$

where $R_{s}$ is the resolution.

The objectives of this study were to optimize a chromatographic method (GC-MS/SIM) for the analysis of PCBs and to determine these compounds in a Fuller's earth sample provided by an electric power company.

\section{Experimental}

\section{Chemicals and materials}

The solvents (GC-grade $n$-hexane and acetone) were purchased from J.T. Baker (Xalostoc, Mexico). High-purity water was produced by a Millipore Milli-Q System (Waters, Midford, MA, USA). PCB analytical standards (Aroclors 1242, 1254, and 1260) and transformer oil (PCB-free) were obtained from Sigma-Aldrich (Milwaukee, USA), all with purity higher than 99\%. DB-5MS $(30 \mathrm{~m} \times 0.25 \mathrm{~mm} \times 0.25 \mu \mathrm{m})$ and Supelco WAX $(30 \mathrm{~m} \times 0.25 \mathrm{~mm} \times 0.25 \mu \mathrm{m})$ chromatographic columns were obtained from Agilent and Supelco, respectively. GC-MS analyses were performed using a Model 7890A/5975C system (Agilent, Walnut Creek, CA, USA).

\section{Analysis of PCBs}

The GC-MS method for PCBs was designed considering the fragments of each PCB in the MS scan analysis (Table 1).

The parameters $\mathrm{k}^{*}$ and $\alpha$ are governed by the conditions that affect retention or the equilibrium distribution of the analyte between the sample and the column phase, according to temperature. ${ }^{23}$ Evaluation was therefore made of the effect of the column phase and temperature on the resolution of the PCBs.

Table 1. PCBs retention times $\left(t_{R}\right)$ and fragmentation using GC-MS (SCAN mode)

\begin{tabular}{lcc}
\hline $\mathrm{t}_{\mathrm{R}} / \mathrm{min}$ & PCBs & Fragmentation \\
\hline 4.99 & 3-chlorobiphenyl & 152,188 \\
5.769 & $1,1^{\prime}$-biphenyl, 2,2'-dichloro- & $152,187,222$ \\
7.025 & $1,1^{\prime}$ '-biphenyl, 2,3'-dichloro- & $152,186,222$ \\
6.373 & $1,1^{\prime}$-'biphenyl, 4,4'-dichloro- & $152,186,222$ \\
6.725 & $1,1^{\prime}$ '-biphenyl, 2,2',3-trichloro- & $150,186,221,258$ \\
7.108 & $1,1^{\prime}$-biphenyl, 2,2',6-trichloro- & $150,186,221,258$ \\
10.161 & $2,2^{\prime}, 3,6$-tetrachloro-1,1'-biphenyl & $150,184,220,255,292$ \\
10.921 & $1,1^{\prime}$-biphenyl, 2,2',3,4',5-pentachloro & $149,184,220,254,292,326$ \\
21.125 & $1,1^{\prime}$-biphenyl, 2,2',3,4,4',5,6,6'-octachloro & $179,207,287,358,393,428$ \\
\hline
\end{tabular}

PCB: polychlorinated biphenyl. 
Changes in the stationary phase generally affect both $\mathrm{k}^{*}$ and $\alpha$, but have less effect on $\mathrm{N}$. The column plate number $(\mathrm{N})$ is primarily dependent on column quality and can be varied by changing the flow rate. Alteration of these conditions will not affect $\mathrm{k}^{*}$ or $\alpha$, as long as the types of mobile phase and stationary phase are not changed. The effect of the flow rate was studied for the optimization of $\mathrm{N}$.

The retention $\left(\mathrm{k}^{*}\right)$ was calculated using equation $2,{ }^{24}$ employing the experimental data.

$\mathrm{k}^{*}=\frac{\mathrm{t}_{\mathrm{R}}-\mathrm{t}_{0}}{\mathrm{t}_{0}}$, where $\mathrm{t}_{0}=\frac{\mathrm{V}_{\mathrm{m}}}{\mathrm{F}}$

where $t_{R}$ is the band retention time, $t_{0}$ is the column dead time, $\mathrm{V}_{\mathrm{m}}$ is the column dead volume, and $\mathrm{F}$ is the flow rate. ${ }^{24}$

\section{Extraction method}

The PCBs were extracted from the Fuller's earth using a hexane and acetone solvent mixture. ${ }^{25}$ The Fuller's earth $(10.0 \mathrm{~g})$ was placed into a $200 \mathrm{~mL}$ Erlenmeyer flask, protected from light, and three $20 \mathrm{~mL}$ volumes of hexane:acetone $(1: 1, \mathrm{v} / \mathrm{v})$ were added to it over $10 \mathrm{~min}$, under ultrasonication. After this step, cleanup of the extract was performed with Florisil, followed by concentration to around $1 \mathrm{~mL}$ in a rotary evaporator at $40{ }^{\circ} \mathrm{C}$. The concentrated extract was quantitatively transferred to a $2 \mathrm{~mL}$ amber vial and was dried using a gentle flow of nitrogen. The residue was re-dissolved in $500 \mu \mathrm{L}$ of $n$-hexane. Quantification of the PCBs in the extract was performed by GC-MS/SIM.

\section{Quantification}

The external standards graphical method was used for quantification. Triplicate injections (autosampler) of $0.80 \mu \mathrm{L}$ of PCBs standard solution (at least five concentrations) were used to construct the analytical curves. Anomalous values were rejected statistically (Statistica 6.0 software), ${ }^{26}$ using Huber's test. ${ }^{27}$ The accuracy of the method was estimated by analysis of mineral oil (free from PCBs) spiked with the analytes. Extraction of the PCBs at three concentration levels $\left(1,10\right.$, and $20 \mu \mathrm{g} \mathrm{kg}^{-1}$ of Fuller's earth) was performed using the same procedure employed for the samples. The analytical process was performed in triplicate. The limits of quantification (LOQ, expressed as $\mu \mathrm{g} \mathrm{kg}^{-1}$ ) were calculated considering a $10.0 \mathrm{~g}$ mass of sample. The limit of detection (LOD) was calculated as 3.3 times the value obtained by dividing the standard deviation of the blank (s) by the angular coefficient of the analytical curve (S). The limit of quantification (LOQ) was calculated as 10 times the value of $\mathrm{s} / \mathrm{S} .{ }^{28}$
The samples were injected in triplicate, with the sample injections interspersed with injections of solutions of standards and solvent ( $n$-hexane), always taking care to avoid cross-contamination.

\section{Results and Discussion}

In the first step, $\mathrm{k}^{*}$ was optimized using the following temperature program: $60^{\circ} \mathrm{C}(3 \mathrm{~min}), 10^{\circ} \mathrm{C} \mathrm{min}^{-1}$ to $250^{\circ} \mathrm{C}$ (15 min), $5{ }^{\circ} \mathrm{C} \mathrm{min}^{-1}$ to $300{ }^{\circ} \mathrm{C} .{ }^{25}$ The composition of the stationary phase was varied, using DB-5MS (5\% phenyl, 95\% dimethylpolysiloxane) and SupelcoWax (SWAX, poly(ethylene glycol)) columns. The temperature program was set so that $\mathrm{k}^{*}$ ranged from 1.93 (3-chlorobiphenyl) to 17.1 (1,1'-biphenyl, 2,2',3,4,4',5,6,6'-octachloro), enabling the detection of 55 PCBs using the SWAX column and 67 compounds using the DB-5MS column. The detection of a greater number of compounds in the latter case was due to the similarity between the stationary phase (5\% phenyl, 95\% dimethylpolysiloxane) and the PCBs. Gas chromatography retention factors ranging from 3.62 to 10.53 have been reported previously for PCB congeners $(28,52,101,118,138,153$, and 180), using three types of column..$^{29}$

The retentions were satisfactory, because the temperature adjustment led to all the bands being within a $\mathrm{k}^{*}$ range of around 0.5 to $20 .{ }^{24}$ This $\mathrm{k}^{*}$ range generally avoids problems related to initial baseline disturbance. When $\mathrm{k}^{*}>20$, excessive peak broadening and long run times are expected.

The temperature program and stationary phase are very important parameters determining the chromatographic resolution of PCBs, especially when samples contain fifty or more compounds, which can lead to poor separation and inaccurate quantification. In the present case, the best separation was achieved using the column with chemical similarity to the PCBs (DB-5MS; $30 \mathrm{~m} \times 0.25 \mathrm{~mm} \times 2.5 \mu \mathrm{m})$ and the following temperature program: $110{ }^{\circ} \mathrm{C}(1 \mathrm{~min}), 25^{\circ} \mathrm{C} \mathrm{m^{-1 }}$ to $200{ }^{\circ} \mathrm{C}(1 \mathrm{~min})$, $2{ }^{\circ} \mathrm{C} \min ^{-1}$ to $260{ }^{\circ} \mathrm{C}(1 \mathrm{~min})$.

Once the retention and selectivity had been adjusted to improve the separation, $\mathrm{N}$ could be increased or decreased, without affecting $\mathrm{k}^{*}$ or $\alpha$. The simplest and most convenient change in column conditions was the increase in flow rate. The plate height $(\mathrm{H})$ varied with the flow rate of the mobile phase, as shown in Figure 1. The optimum flow rate was $1.4 \mathrm{~mL} \mathrm{~min}^{-1}$, which provided higher resolution

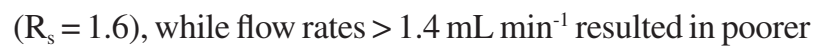
mass spectra and lower sensitivity. The chromatographic separation was optimized using the nonpolar column (DB-5MS) and helium flow rate of $1.4 \mathrm{~mL} \mathrm{~min}^{-1}$. Selectivity $(\alpha)$ optimization was achieved considering the 
changes in chromatographic resolution for 1,1'-biphenyl, 2,2',3-trichloro and 1,1'-biphenyl, 2,2',6-trichloro- (worse resolution), according to the temperature program.

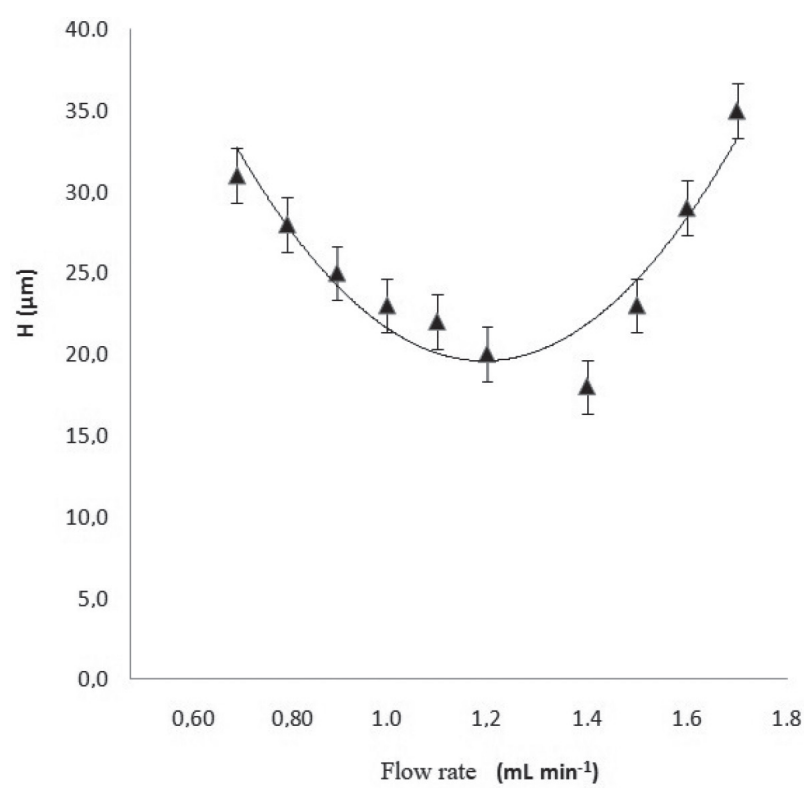

Figure 1. Variation of plate height $(\mathrm{H})$ with helium flow rate.

A comparison of the performance of the method developed here and methods reported in the literature ${ }^{11,13,25}$ is provided in Table 2, considering the number of PCBs detected and the analytical response.

Figure 2 shows a chromatogram of the PCBs after optimization of the parameters that influenced chromatographic resolution.
Table 2. Comparison of methods reported in the literature ${ }^{11,13,25}$ and the method developed in the present work with optimization of $\mathrm{k}^{*}, \alpha$, and $\mathrm{N}$

\begin{tabular}{lcc}
\hline Method & PCBs detected & Analysis time / min \\
\hline Ayris et $_{\text {al. }}{ }^{25}$ & 80 & 47 \\
Baker & 73 & 32 \\
EPA & 75 & 48 \\
This work & 83 & 35 \\
\hline
\end{tabular}

PCB: polychlorinated biphenyl. PCBs standard concentration: $1.57 \mu \mathrm{g} \mathrm{mL} \mathrm{m}^{-1}$.

The optimization of the chromatographic parameters $\mathrm{k}^{*}$, $\alpha$, and $\mathrm{N}$, independent of each other, was very important for achieving the desired separation $\left(\mathrm{R}_{\mathrm{s}}>1.5\right)$ of the PCBs, together with a satisfactory analysis time (35 min), using only a few experiments. The analysis time was similar to the time of $37 \mathrm{~min}$ reported by Zhang et al..$^{30}$ for the analysis of PCB congeners present in a soil matrix.

The recoveries of the PCBs from Fuller's earth were evaluated by extraction and analysis of this material spiked with the analytes. The recoveries were in the range $72-93 \%$ (Table 3), except for 3-chlorobiphenyl and 1,1'-biphenyl, 2,2'-dichloro, which showed low recoveries (mean of 49\%), probably due to their high vapor pressures. In addition, 3-chlorobiphenyl presented a low mass spectrometric response and was therefore difficult to detect using GC-MS with positive ionization.

Similar results were reported by Halfadji and Touabet, ${ }^{31}$ who analyzed 26 PCB congeners present in spiked soil samples, using hexane and acetone as solvents, with

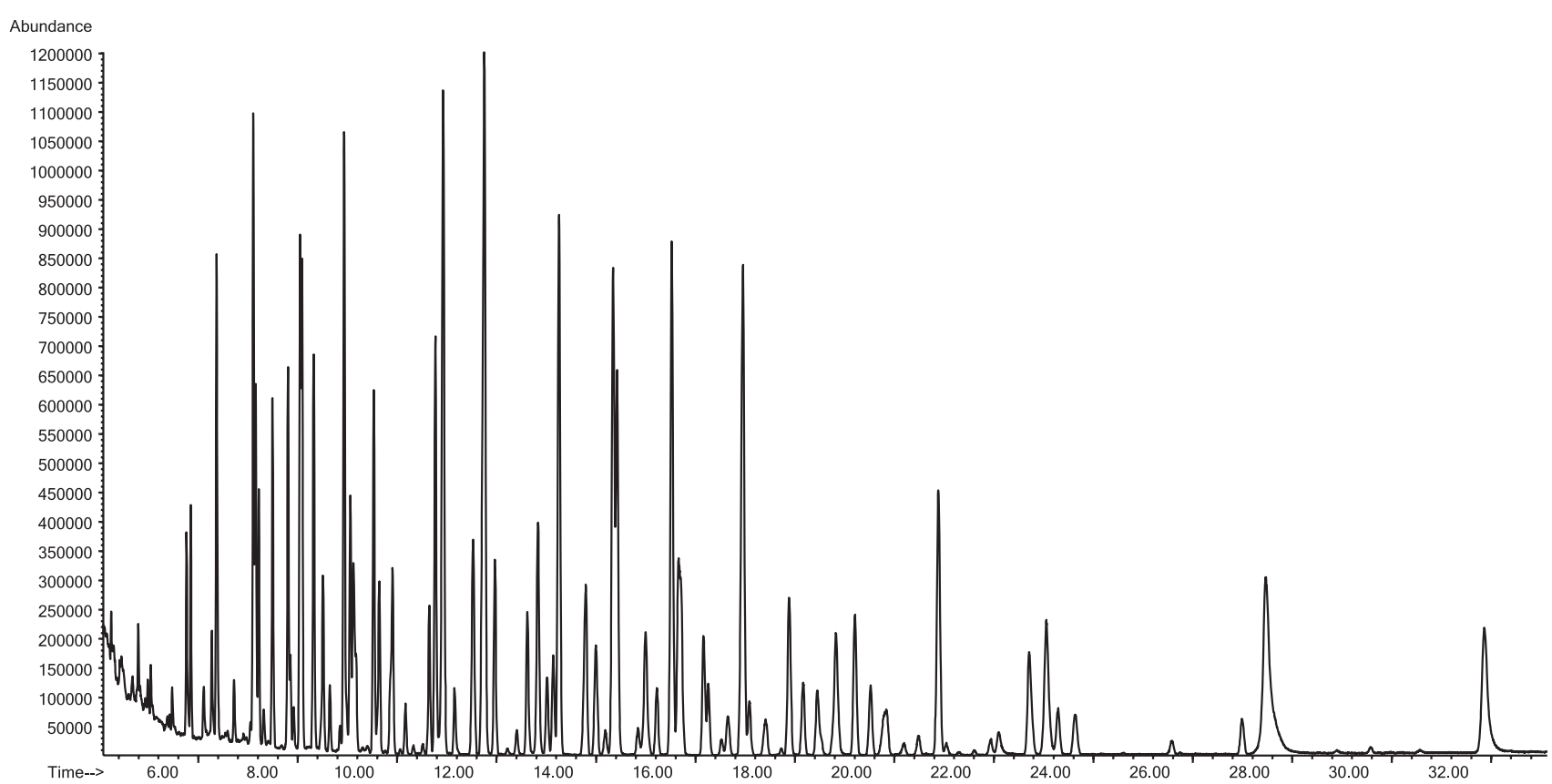

Figure 2. Chromatogram of 83 PCBs after optimization of effective retention $\left(k^{*}\right)$, selectivity $(\alpha)$, and column efficiency $(\mathrm{N})$. 
Table 3. Recoveries of PCBs from Fuller's earth (mass of $10.0 \mathrm{~g}$ ) spiked with the Aroclors

\begin{tabular}{|c|c|c|c|c|c|c|c|c|}
\hline \multirow{3}{*}{ PCBs (Aroclor) } & \multicolumn{6}{|c|}{ Spiked value (concentration) } & \multirow{2}{*}{\multicolumn{2}{|c|}{$\begin{array}{l}\text { Recoveries reported in } \\
\text { the literature }{ }^{20}\end{array}$}} \\
\hline & \multicolumn{2}{|c|}{$1 \mu \mathrm{kg}^{-1}$} & \multicolumn{2}{|c|}{$10 \mu \mathrm{g} \mathrm{kg}^{-1}$} & \multicolumn{2}{|c|}{$20 \mu \mathrm{g} \mathrm{kg}^{-1}$} & & \\
\hline & $\operatorname{Rec} / \%$ & $\mathrm{CV} / \%$ & $\operatorname{Rec} / \%$ & $\mathrm{CV} / \%$ & $\operatorname{Rec} / \%$ & $\mathrm{CV} / \%$ & $\operatorname{Rec} / \%$ & $\mathrm{CV} / \%$ \\
\hline 1242 & 87 & 10 & 83 & 13 & 89 & 12 & 89 & 8 \\
\hline 1254 & 89 & 13 & 93 & 12 & 87 & 15 & 99 & 7 \\
\hline 1260 & 77 & 9 & 74 & 12 & 80 & 11 & 95 & 9 \\
\hline
\end{tabular}

PCB: polychlorinated biphenyl; Rec: recoveries; CV: coefficient of variation.

recoveries of $84.7-117 \%$ and relative standard deviation (RSD) less than $10 \%$.

The LOD and LOQ obtained for the analysis of Fuller's earth were 0.19 and $0.64 \mu \mathrm{g} \mathrm{kg}^{-1}$, respectively. Previous work $^{30}$ using solid phase microextraction (SPME) and GC-MS reported limits of detection of around $10 \mathrm{ppm}$ for Aroclor 1260 present in fortified soil samples. Elsewhere, LOD and LOQ values in the ranges 0.03-0.27 and $0.11-0.70 \mu \mathrm{g} \mathrm{kg}-1$, respectively, were reported for the analysis of 26 PCBs by gas chromatography with electron capture detection (GC-ECD). ${ }^{31}$

The mass spectra of the substances in the chromatograms were compared with the data available in the National Institute of Standards and Technology library (NIST, 2011). ${ }^{32}$ The match factor values obtained are shown in Figure 3. In this procedure, the match factor values can range from 0 (no match) to 1000 (perfect match). Values of
900 or higher are considered to indicate a very good match; between 800 and 900, a good match; between 700 and 800 , a fair match; and less than 600 , a very poor match. ${ }^{32}$

The probability values found by the software were between 15 and $78 \%$. These values consider the probability that a hit is correct, assuming that the matching compound is present in the library.

Determination of the levels of PCBs was performed in the Fuller's earth sample provided by the electricity supply company. The mean concentration for total PCBs was $1.91 \mu \mathrm{g} \mathrm{kg}^{-1}$ (Table 4).

Since the compounds found are considered carcinogenic and/or mutagenic, ${ }^{33}$ the material should be treated before being released to the environment. Table 5 provides a summary of all the PCB retention times obtained using the optimized method, together with the molecular weights and formulae of the compounds.

\section{(a) Quality of spectral mass $\mathrm{m} / \mathrm{z}$ of Pcbs}

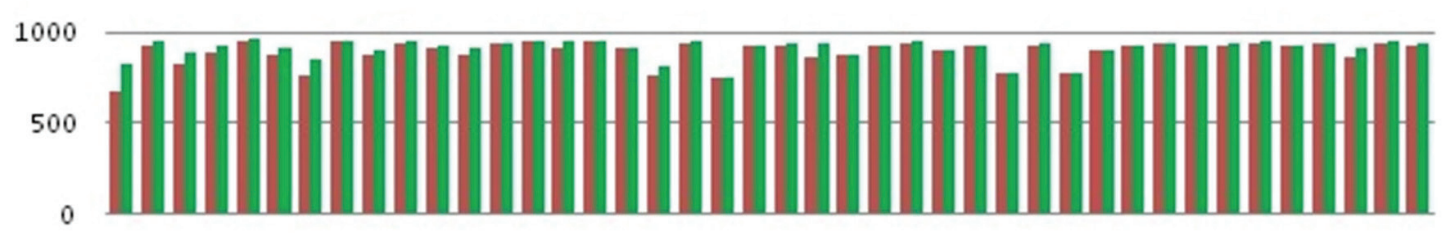

123456789101112131415161718192021222324252627282930313233343536373839404142

a Match $\quad$ R. Match

(b) Quality of mass $\mathrm{m} / \mathrm{z}$ of Pcbs

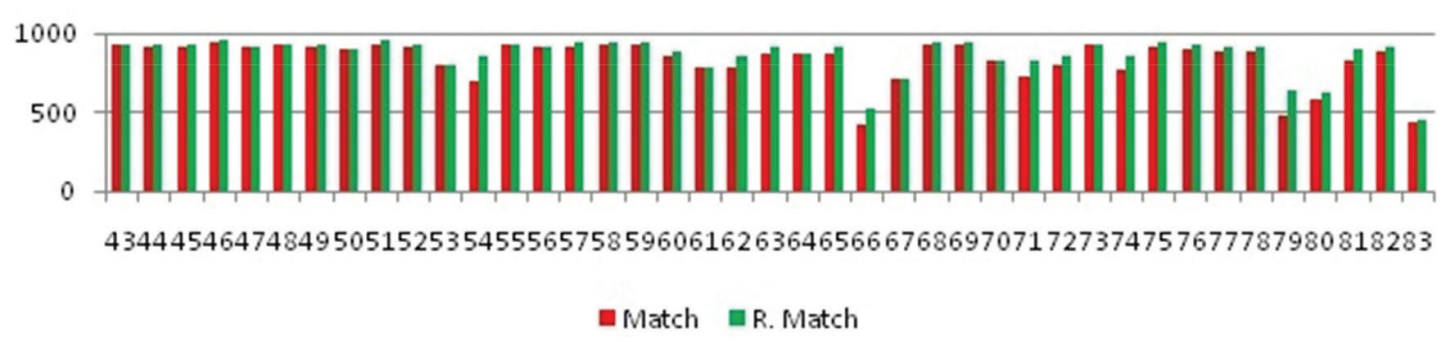

Figure 3. Qualities of the mass spectra determined by the NIST Match and Reverse Match (R. Match) factor methods for (a) 1-42 and (b) $43-83$ PCBs. 
Table 4. Concentration of PCBs congener mixtures $(1242,1254$, and 1260) in Fuller's earth

\begin{tabular}{lcc}
\hline Aroclor & Individual / $\left(\mu \mathrm{g} \mathrm{kg}{ }^{-1}\right)$ & Most abundant PCBs \\
\hline 1242 & 0.34 & $1,1^{\prime}$ 'biphenyl 2,3'-dichloro and 1,1'-biphenyl, 2,2',5-trichloro- \\
1254 & 0.86 & $1,1^{\prime}$-biphenyl, 2,3,3',4'-tetrachloro- and 2,2',3,4',5,6-hexachloro-1,1'-biphenyl \\
1260 & 0.71 & $1,1^{\prime}$ '-biphenyl, 2,2',3,3',4,5,6'-heptachloro and 1,1'-biphenyl, 2,2',3,4,4',5,6,6'-octachloro \\
\hline$\Sigma$ PCBs / $\left(\mu \mathrm{g} \mathrm{kg}^{-1}\right)$ & 1.91 & \\
\hline PCB: & &
\end{tabular}

PCB: polychlorinated biphenyl.

Table 5. Identification of the PCBs, their retention times, and corresponding molecular weights and formulae

\begin{tabular}{|c|c|c|c|c|c|c|c|c|c|c|c|}
\hline Sub. & $\mathrm{t}_{\mathrm{R}} / \min$ & Nomenclature & PCB & M.F. & M.W. & Sub. & $\mathrm{t}_{\mathrm{R}} / \min$ & Nomenclature & PCB & M.F. & M.W. \\
\hline 1 & 4.990 & 3-chlorobiphenyl & PCB 2 & $\mathrm{C}_{12} \mathrm{H}_{9} \mathrm{Cl}$ & 188.039 & 43 & 14.425 & 1,1'-biphenyl, 2,3,3',4,6-pentachloro- & PCB 109 & $\mathrm{C}_{12} \mathrm{H}_{5} \mathrm{Cl}_{5}$ & 323.883 \\
\hline 2 & 5.769 & 1,1'-biphenyl, 2,2'-dichloro- & PCB 4 & $\mathrm{C}_{12} \mathrm{H}_{8} \mathrm{Cl}_{2}$ & 222.000 & 44 & 14.849 & $\begin{array}{c}\text { 1,1'-biphenyl, } \\
2,2^{\prime}, 3,3 \text { ', } 4,6^{\prime} \text {-hexachloro- }\end{array}$ & PCB 132 & $\mathrm{C}_{12} \mathrm{H}_{4} \mathrm{Cl}_{6}$ & 357.844 \\
\hline 3 & 6.110 & 1,1'-biphenyl, 3,3'-dichloro- & PCB 11 & $\mathrm{C}_{12} \mathrm{H}_{8} \mathrm{Cl}_{2}$ & 222.000 & 45 & 15.224 & $\begin{array}{c}\text { 1,1'-biphenyl, } \\
2,2^{\prime}, 3,3 \text { ', } 4,6^{\prime} \text {-hexachloro- }\end{array}$ & PCB 132 & $\mathrm{C}_{12} \mathrm{H}_{4} \mathrm{Cl}_{6}$ & 357.844 \\
\hline 4 & 6.276 & 2,5-dichloro-1,1'-biphenyl & PCB 9 & $\mathrm{C}_{12} \mathrm{H}_{8} \mathrm{Cl}_{2}$ & 222.000 & 46 & 15.525 & $\begin{array}{c}\text { 1,1'-biphenyl, } \\
2,2^{\prime}, 3,3 \text { ',4,5'-hexachloro- }\end{array}$ & PCB 152 & $\mathrm{C}_{12} \mathrm{H}_{4} \mathrm{Cl}_{6}$ & 357.844 \\
\hline 5 & 6.373 & 1,1'-biphenyl, 4,4'-dichloro- & PCB 15 & $\mathrm{C}_{12} \mathrm{H}_{8} \mathrm{Cl}_{2}$ & 222.000 & 47 & 15.674 & $\begin{array}{c}\text { 1,1'-biphenyl, } \\
2,2^{\prime}, 3,3^{\prime}, 4,5^{\prime} \text {-hexachloro- }\end{array}$ & PCB 130 & $\mathrm{C}_{12} \mathrm{H}_{4} \mathrm{Cl}_{6}$ & 357.844 \\
\hline 6 & 6.725 & 1,1'-biphenyl, 2,2',3-trichloro- & PCB 16 & $\mathrm{C}_{12} \mathrm{H}_{7} \mathrm{Cl}_{3}$ & 255.961 & 48 & 16.160 & $\begin{array}{c}\text { 1,1'-biphenyl, } \\
2,2^{\prime}, 3,4,4^{\prime}, 5 \text {-hexachloro- }\end{array}$ & PCB 137 & $\mathrm{C}_{12} \mathrm{H}_{4} \mathrm{Cl}_{6}$ & 357.844 \\
\hline 7 & 7.025 & 1,1'-biphenyl, 2,3'-dichloro- & PCB 6 & $\mathrm{C}_{12} \mathrm{H}_{8} \mathrm{Cl}_{2}$ & 222.000 & 49 & 16.267 & $\begin{array}{c}\text { 1,1'-biphenyl, } \\
2,3,3^{\prime}, 4 \text { ',5,5',6-heptachloro- }\end{array}$ & PCB 193 & $\mathrm{C}_{12} \mathrm{H}_{3} \mathrm{Cl}_{7}$ & 391.805 \\
\hline 8 & 7.108 & 1,1'-biphenyl, 2,2',6-trichloro- & PCB 19 & $\mathrm{C}_{12} \mathrm{H}_{7} \mathrm{Cl}_{3}$ & 255.961 & 50 & 16.523 & $\begin{array}{c}\text { 2,2',3,4,6,6'-hexachloro- } \\
\text { 1,1'-biphenyl }\end{array}$ & PCB 145 & $\mathrm{C}_{12} \mathrm{H}_{4} \mathrm{Cl}_{6}$ & 357.844 \\
\hline 9 & 7.213 & 1,1'-biphenyl, 2,2',4-trichloro- & PCB 17 & $\mathrm{C}_{12} \mathrm{H}_{7} \mathrm{Cl}_{3}$ & 255.961 & 51 & 16.956 & $\begin{array}{c}\text { 2,2',3,4,4',6'-hexachloro- } \\
\text { 1,1'-biphenyl }\end{array}$ & PCB 140 & $\mathrm{C}_{12} \mathrm{H}_{4} \mathrm{Cl}_{6}$ & 357.844 \\
\hline 10 & 7.318 & 1,1'-biphenyl, 2,4',5-trichloro- & PCB 31 & $\mathrm{C}_{12} \mathrm{H}_{7} \mathrm{Cl}_{3}$ & 255.961 & 52 & 17.083 & $\begin{array}{c}\text { 2,3,3',4',5',6-hexachloro- } \\
\text { 1,1'-biphenyl }\end{array}$ & PCB 164 & $\mathrm{C}_{12} \mathrm{H}_{4} \mathrm{Cl}_{6}$ & 357.844 \\
\hline 11 & 7.500 & 1,1'-biphenyl, 2,2',5-trichloro- & PCB 18 & $\mathrm{C}_{12} \mathrm{H}_{7} \mathrm{Cl}_{3}$ & 255.961 & 53 & 17.409 & 2,2',3,3',4,5',6-heptachlorobiphenyl & РCB 175 & $\mathrm{C}_{12} \mathrm{H}_{3} \mathrm{Cl}_{7}$ & 391.805 \\
\hline 12 & 7.852 & 1,1'-biphenyl, 2,3,4'-trichloro- & PCB 22 & $\mathrm{C}_{12} \mathrm{H}_{7} \mathrm{Cl}_{3}$ & 255.961 & 54 & 17.735 & $\begin{array}{c}\text { 1,1'-biphenyl, } \\
2,3,3^{\prime}, 4,4^{\prime}, 5,5 \text { '-heptachloro- }\end{array}$ & PCB 189 & $\mathrm{C}_{12} \mathrm{H}_{3} \mathrm{Cl}_{7}$ & 391.805 \\
\hline 13 & 7.924 & 1,1'-biphenyl, 2,3',4-trichloro- & PCB 25 & $\mathrm{C}_{12} \mathrm{H}_{7} \mathrm{Cl}_{3}$ & 255.961 & 55 & 17.887 & $\begin{array}{c}\text { 1,1'-biphenyl, } \\
2,2 \text { ',3,4,4',5,6'-heptachloro- }\end{array}$ & PCB 182 & $\mathrm{C}_{12} \mathrm{H}_{3} \mathrm{Cl}_{7}$ & 391.805 \\
\hline 14 & 8.036 & 1,1'-biphenyl, 2,3',5-trichloro- & PCB 26 & $\mathrm{C}_{12} \mathrm{H}_{7} \mathrm{Cl}_{3}$ & 255.961 & 56 & 18.167 & $\begin{array}{c}\text { 1,1'-biphenyl, } \\
2,2 \text { ',3,4,4',5,6'-heptachloro- }\end{array}$ & PCB 183 & $\mathrm{C}_{12} \mathrm{H}_{3} \mathrm{Cl}_{7}$ & 391.805 \\
\hline 15 & 8.085 & 1,1'-biphenyl, 3,3',4-trichloro & PCB 34 & $\mathrm{C}_{12} \mathrm{H}_{7} \mathrm{Cl}_{3}$ & 255.961 & 57 & 18.458 & $\begin{array}{c}\text { 2,2',3,4',5,6'-hexachloro- } \\
\text { 1,1'-biphenyl }\end{array}$ & PCB 148 & $\mathrm{C}_{12} \mathrm{H}_{4} \mathrm{Cl}_{6}$ & 357.844 \\
\hline 16 & 8.324 & 3,3',5-trichloro-1,1'-biphenyl & PCB 36 & $\mathrm{C}_{12} \mathrm{H}_{7} \mathrm{Cl}_{3}$ & 255.961 & 58 & 19.210 & $\begin{array}{c}\text { 1,1'-biphenyl, } \\
2,2 \text { ',3,3',4,5,6'-heptachloro- }\end{array}$ & PCB 174 & $\mathrm{C}_{12} \mathrm{H}_{3} \mathrm{Cl}_{7}$ & 391.805 \\
\hline 17 & 8.934 & 2,2',4,4'-tetrachlorobiphenyl & PCB 47 & $\mathrm{C}_{12} \mathrm{H}_{6} \mathrm{Cl}_{4}$ & 289.922 & 59 & 19.519 & $\begin{array}{c}\text { 1,1'-biphenyl, } \\
2,2^{\prime}, 3,3 \text { ',4,5,6'-heptachloro- }\end{array}$ & PCB 174 & $\mathrm{C}_{12} \mathrm{H}_{3} \mathrm{Cl}_{8}$ & 391.805 \\
\hline 18 & 9.173 & 2,2',4,5-tetrachloro-1,1'-biphenyl & PCB 48 & $\mathrm{C}_{12} \mathrm{H}_{6} \mathrm{Cl}_{4}$ & 289.922 & 60 & 19.787 & $2,2^{\prime}, 3,3^{\prime}, 4,5^{\prime}, 6$-heptachlorobiphenyl & PCB 175 & $\mathrm{C}_{12} \mathrm{H}_{3} \mathrm{Cl}_{7}$ & 391.805 \\
\hline 19 & 9.412 & 2,4',6-trichloro-1,1'-biphenyl & PCB 32 & $\mathrm{C}_{12} \mathrm{H}_{7} \mathrm{Cl}_{3}$ & 255.961 & 61 & 19.812 & $\begin{array}{c}\text { 2,3,3',4,4',5',6-heptachloro- } \\
\text { 1,1'-biphenyl }\end{array}$ & PCB 191 & $\mathrm{C}_{12} \mathrm{H}_{3} \mathrm{Cl}_{7}$ & 391.805 \\
\hline 20 & 9.532 & $\begin{array}{c}\text { 1,1'-biphenyl, } \\
\text { 2,2',5,6'-tetrachloro- }\end{array}$ & PCB 53 & $\mathrm{C}_{12} \mathrm{H}_{6} \mathrm{Cl}_{4}$ & 289.923 & 62 & 19.824 & $\begin{array}{c}\text { 1,1'-biphenyl, } \\
2,3,3 \text { ',4,5,6-hexachloro- }\end{array}$ & PCB 160 & $\mathrm{C}_{12} \mathrm{H}_{4} \mathrm{Cl}_{6}$ & 357.844 \\
\hline 21 & 9.601 & $\begin{array}{c}\text { 2,2',4,6'-tetrachloro- } \\
\text { 1,1'-biphenyl }\end{array}$ & PCB 51 & $\mathrm{C}_{12} \mathrm{H}_{6} \mathrm{Cl}_{4}$ & 289.922 & 63 & 19.842 & $\begin{array}{c}\text { 2,3,3',5,5',6-hexachloro- } \\
\text { 1,1'-biphenyl }\end{array}$ & PCB 165 & $\mathrm{C}_{12} \mathrm{H}_{4} \mathrm{Cl}_{6}$ & 357.844 \\
\hline 22 & 9.907 & $\begin{array}{c}\text { 1,1'-biphenyl, } \\
2,3^{\prime}, 5,5 \text { '-tetrachloro- }\end{array}$ & PCB 72 & $\mathrm{C}_{12} \mathrm{H}_{6} \mathrm{Cl}_{4}$ & 289.922 & 64 & 19.787 & 2,2',3,3',4,5',6-heptachlorobiphenyl & PCB 175 & $\mathrm{C}_{12} \mathrm{H}_{3} \mathrm{Cl}_{7}$ & 391.805 \\
\hline 23 & 10.161 & $\begin{array}{l}\text { 2,2',3,6-tetrachloro- } \\
\text { 1,1'-biphenyl }\end{array}$ & PCB 45 & $\mathrm{C}_{12} \mathrm{H}_{6} \mathrm{Cl}_{4}$ & 289.922 & 65 & 19.845 & $\begin{array}{c}\text { 2,3,3',5,5',6-hexachloro- } \\
\text { 1,1'-biphenyl }\end{array}$ & PCB 165 & $\mathrm{C}_{12} \mathrm{H}_{4} \mathrm{Cl}_{6}$ & 357.844 \\
\hline 24 & 10.517 & $\begin{array}{c}\text { 1,1'-biphenyl, } \\
\text { 3,3',5,5' -tetrachloro- }\end{array}$ & PCB 80 & $\mathrm{C}_{12} \mathrm{H}_{6} \mathrm{Cl}_{4}$ & 289.922 & 66 & 20.125 & $\begin{array}{c}\text { 1,1'-biphenyl, } \\
2,2 \text { ',3,4,4',5,6,6'-octachloro- }\end{array}$ & PCB 189 & $\mathrm{C}_{12} \mathrm{H}_{2} \mathrm{Cl}_{8}$ & 425.766 \\
\hline 25 & 10.525 & $\begin{array}{l}\text { 2,3,4',5-tetrachloro- } \\
\text { 1,1'-biphenyl }\end{array}$ & PCB 63 & $\mathrm{C}_{12} \mathrm{H}_{6} \mathrm{Cl}_{4}$ & 289.922 & 67 & 20.191 & $\begin{array}{c}\text { 1,1'-biphenyl, } \\
2,2^{\prime}, 3,4,4^{\prime}, 5,6,6 \text { '-octachloro- }\end{array}$ & PCB 204 & $\mathrm{C}_{12} \mathrm{H}_{2} \mathrm{Cl}_{8}$ & 425.766 \\
\hline 26 & 10.653 & $\begin{array}{c}\text { 2,3',4,5-tetrachloro- } \\
\text { 1,1'-biphenyl }\end{array}$ & PCB 67 & $\mathrm{C}_{12} \mathrm{H}_{6} \mathrm{Cl}_{4}$ & 289.922 & 68 & 20.892 & $\begin{array}{c}\text { 1,1'-biphenyl, } \\
2,2^{\prime}, 3,3 \text { ',5,6,6'-heptachloro- }\end{array}$ & PCB 172 & $\mathrm{C}_{12} \mathrm{H}_{2} \mathrm{Cl}_{8}$ & 425.766 \\
\hline
\end{tabular}


Table 5. Identification of the PCBs, their retention times, and corresponding molecular weights and formulae (cont.)

\begin{tabular}{|c|c|c|c|c|c|c|c|c|c|c|c|}
\hline Sub. & $\mathrm{t}_{\mathrm{R}} / \mathrm{min}$ & Nomenclature & РСB & M.F. & M.W. & Sub. & $t_{R} / \min$ & Nomenclature & РCB & M.F. & M.W. \\
\hline 27 & 10.769 & $\begin{array}{c}\text { 1,1'-biphenyl, } \\
\text { 2,3,3',4'-tetrachloro- }\end{array}$ & РCB 56 & $\mathrm{C}_{12} \mathrm{H}_{6} \mathrm{Cl}_{4}$ & 289.922 & 69 & 20.888 & $\begin{array}{c}\text { 1,1'-biphenyl, } \\
2,2^{\prime}, 3,3^{\prime}, 5,6,6 \text { '-heptachloro- }\end{array}$ & РСВ 179 & $\mathrm{C}_{12} \mathrm{H}_{3} \mathrm{Cl}_{7}$ & 391.805 \\
\hline 28 & 10.921 & $\begin{array}{c}\text { 1,1'-biphenyl, } \\
2,2^{\prime}, 3,4^{\prime}, 5 \text {-pentachloro }\end{array}$ & РCB 90 & $\mathrm{C}_{12} \mathrm{H}_{5} \mathrm{Cl}_{5}$ & 323.883 & 70 & 21.041 & $\begin{array}{c}\text { 1,1'-biphenyl, } \\
2,3,3^{\prime}, 4^{\prime}, 5,5^{\prime}, 6 \text {-heptachloro- }\end{array}$ & РCB 193 & $\mathrm{C}_{12} \mathrm{H}_{3} \mathrm{Cl}_{7}$ & 391.805 \\
\hline 29 & 11.156 & 2,2',4,5,5'-pentachlorobiphenyl & РСB 101 & $\mathrm{C}_{12} \mathrm{H}_{5} \mathrm{Cl}_{5}$ & 323.883 & 71 & 21.300 & $\begin{array}{c}\text { 1,1'-biphenyl, } \\
2,3,3^{\prime}, 4,4^{\prime}, 5,5 \text { '-heptachloro- }\end{array}$ & РCB 189 & $\mathrm{C}_{12} \mathrm{H}_{3} \mathrm{Cl}_{7}$ & 391.805 \\
\hline 30 & 11.535 & $\begin{array}{c}\text { 1,1'-biphenyl, } \\
\text { 2,3,3',4'-tetrachloro- }\end{array}$ & РСВ 117 & $\mathrm{C}_{12} \mathrm{H}_{5} \mathrm{Cl}_{5}$ & 289.922 & 72 & 21.613 & $\begin{array}{c}\text { 1,1'-biphenyl, } \\
2,2^{\prime}, 3,3^{\prime}, 4,5,6,6 \text { '-octachloro- }\end{array}$ & РСB 200 & $\mathrm{C}_{12} \mathrm{H}_{2} \mathrm{Cl}_{8}$ & 425.766 \\
\hline 31 & 11.909 & $\begin{array}{c}\text { 1,1'-biphenyl, } \\
2,2^{\prime}, 4,4^{\prime}, 5 \text {-pentachloro- }\end{array}$ & РСВ 99 & $\mathrm{C}_{12} \mathrm{H}_{5} \mathrm{Cl}_{5}$ & 323.883 & 73 & 22.710 & $\begin{array}{c}\text { 1,1'-biphenyl, } \\
2,2^{\prime}, 3,3^{\prime}, 4,5,6^{\prime} \text {-heptachloro- }\end{array}$ & РCB 174 & $\mathrm{C}_{12} \mathrm{H}_{3} \mathrm{Cl}_{7}$ & 391.805 \\
\hline 32 & 12.224 & $\begin{array}{l}\text { 2,3,3', } 4^{\prime}, 5 \text {-pentachloro- } \\
\text { 1,1'-biphenyl }\end{array}$ & РСВ 107 & $\mathrm{C}_{12} \mathrm{H}_{5} \mathrm{Cl}_{5}$ & 323.883 & 74 & 21.617 & $\begin{array}{c}\text { 1,1'-biphenyl, } \\
2,2^{\prime}, 3,3^{\prime}, 4,4^{\prime}, 6,6 \text { '-octachloro- }\end{array}$ & РCB 197 & $\mathrm{C}_{12} \mathrm{H}_{2} \mathrm{Cl}_{8}$ & 425.766 \\
\hline 33 & 12.409 & $\begin{array}{c}\text { 1,1'-biphenyl, } \\
\text { 2,2',3,3',6-pentachloro- }\end{array}$ & РCB 84 & $\mathrm{C}_{12} \mathrm{H}_{5} \mathrm{Cl}_{5}$ & 323.883 & 75 & 22.710 & $\begin{array}{c}\text { 1,1'-biphenyl, } \\
2,2^{\prime}, 3,3^{\prime}, 4,5^{\prime}, 6^{\prime} \text { '-heptachloro }\end{array}$ & РCB 177 & $\mathrm{C}_{12} \mathrm{H}_{3} \mathrm{Cl}_{7}$ & 391.805 \\
\hline 34 & 12.623 & $\begin{array}{l}\text { 2,2',3,4',6-pentachloro-1,1'- } \\
\text { biphenyl }\end{array}$ & РСВ 91 & $\mathrm{C}_{12} \mathrm{H}_{5} \mathrm{Cl}_{5}$ & 323.883 & 76 & 22.759 & $\begin{array}{c}\text { 1,1'-biphenyl, } \\
2,2^{\prime}, 3,3^{\prime}, 5,6,6 \text { '-heptachloro- }\end{array}$ & РСВ 179 & $\mathrm{C}_{12} \mathrm{H}_{3} \mathrm{Cl}_{7}$ & 391.805 \\
\hline 35 & 12.834 & $\begin{array}{c}\text { 1,1'-biphenyl, } \\
2,2^{2}, 3,3 \text { ',6-pentachloro- }\end{array}$ & РCB 84 & $\mathrm{C}_{12} \mathrm{H}_{5} \mathrm{Cl}_{5}$ & 323.883 & 77 & 23.295 & $\begin{array}{c}\text { 1,1'-biphenyl, } \\
2,2^{\prime}, 3,3^{\prime}, 4,4^{\prime}, 5,6^{\prime} \text {-octachloro- }\end{array}$ & РCB 196 & $\mathrm{C}_{12} \mathrm{H}_{2} \mathrm{Cl}_{8}$ & 425.766 \\
\hline 36 & 13.015 & $\begin{array}{c}\text { 1,1'-biphenyl, } \\
2,2^{\prime}, 4,5,5^{\prime} \text {-pentachloro- }\end{array}$ & РСB 101 & $\mathrm{C}_{12} \mathrm{H}_{5} \mathrm{Cl}_{5}$ & 323.883 & 78 & 23.637 & $\begin{array}{c}2,2^{\prime}, 3,4,4^{\prime}, 5,5^{\prime}, 6 \text {-octachloro- } \\
\text { \1,1'-biphenyl }\end{array}$ & РCB 203 & $\mathrm{C}_{12} \mathrm{H}_{2} \mathrm{Cl}_{8}$ & 425.766 \\
\hline 37 & 13.139 & $\begin{array}{l}2,2^{\prime}, 3,4,6,6^{\prime} \text {-hexachloro-1,1'- } \\
\text { biphenyl }\end{array}$ & РCB 145 & $\mathrm{C}_{12} \mathrm{H}_{4} \mathrm{Cl}_{6}$ & 357.844 & 79 & 24.584 & $\begin{array}{c}\text { 1,1'-biphenyl, } \\
2,3,3^{\prime}, 4,4^{\prime}, 5,5 \text { '-heptachloro- }\end{array}$ & РCB 189 & $\mathrm{C}_{12} \mathrm{H}_{3} \mathrm{Cl}_{7}$ & 391.805 \\
\hline 38 & 13.262 & $\begin{array}{c}\text { 1,1'-biphenyl, } \\
2,3 \text { ',4,5,5'-pentachloro- }\end{array}$ & РCB 120 & $\mathrm{C}_{12} \mathrm{H}_{5} \mathrm{Cl}_{5}$ & 323.883 & 80 & 24.610 & 2,2',3,3',4,5',6-heptachlorobiphenyl & PCB 175 & $\mathrm{C}_{12} \mathrm{H}_{3} \mathrm{Cl}_{7}$ & 391.805 \\
\hline 39 & 13.790 & $\begin{array}{c}\text { 1,1'-biphenyl, } \\
2,2^{\prime}, 3,3^{\prime}, 4,5^{\prime} \text { '-hexachloro- }\end{array}$ & РCB 130 & $\mathrm{C}_{12} \mathrm{H}_{4} \mathrm{Cl}_{6}$ & 357.844 & 81 & 25.546 & $\begin{array}{c}\text { 1,1'-biphenyl, } \\
2,2^{\prime}, 3,3^{\prime}, 4,5,5^{\prime}, 6^{\prime} \text {-octachloro- }\end{array}$ & РCB 199 & $\mathrm{C}_{12} \mathrm{H}_{2} \mathrm{Cl}_{8}$ & 425.766 \\
\hline 40 & 14.000 & $\begin{array}{l}\text { 2,2',3,4',5,6-hexachloro-1,1'- } \\
\text { biphenyl }\end{array}$ & РСB 147 & $\mathrm{C}_{12} \mathrm{H}_{4} \mathrm{Cl}_{6}$ & 357.844 & 82 & 26.993 & $\begin{array}{c}2,2^{\prime}, 3,4,4^{\prime}, 5,55^{\prime}, 6 \text {-octachloro- } \\
1,1^{\prime} \text {-biphenyl }\end{array}$ & РСВ 203 & $\mathrm{C}_{12} \mathrm{H}_{2} \mathrm{Cl}_{8}$ & 425.766 \\
\hline 41 & 14.198 & $\begin{array}{c}\text { 1,1'-biphenyl, } \\
2,3 \text { ', } 4,5,5 \text { '-pentachloro- }\end{array}$ & РСB 120 & $\mathrm{C}_{12} \mathrm{H}_{5} \mathrm{Cl}_{5}$ & 323.883 & 83 & 29.589 & $\begin{array}{c}\text { 1,1'-biphenyl, } \\
2,2^{\prime}, 3,3^{\prime}, 4,5,5^{\prime}, 6,6 \text { '-nonachloro- }\end{array}$ & РCB 208 & $\mathrm{C}_{12} \mathrm{HCl}_{9}$ & 459.727 \\
\hline 42 & 14.350 & $\begin{array}{c}2,2^{\prime}, 3,4^{\prime}, 5,6^{\prime} \text {-hexachloro-1,1'- } \\
\text { biphenyl }\end{array}$ & РСB 148 & $\mathrm{C}_{12} \mathrm{H}_{4} \mathrm{Cl}_{6}$ & 357.844 & & & & & & \\
\hline
\end{tabular}

Sub.: substance; $\mathrm{t}_{\mathrm{R}}$ : retention time; PCB: polychlorinated biphenyl; M.F.: molecular formula; M.W.: molecular weight.

\section{Conclusions}

The 5\% phenyl/95\% dimethylpolysiloxane column stationary phase provided greater selectivity than the poly(ethylene glycol) phase, mainly due to the combination of dipole and hydrogen-bonding interactions with the PCBs, resulting in rapid separation of all 83 PCBs, without loss of resolution or broadening of later bands.

The presence of nontarget compounds in the sample could be identified by comparing the mass spectral results with data available in the NIST library.

The use of the automatic injection $(0.80 \mu \mathrm{L}$ in a split mode (1:20), injection temperature: $280{ }^{\circ} \mathrm{C}$ ), DB-5MS $(30 \mathrm{~m} \times 0.25 \mathrm{~mm} \times 0.25 \mu \mathrm{m})$ column (carrier gas: helium $\left.1.40 \mathrm{~mL} \mathrm{~min}{ }^{-1}\right)$, together with an optimized temperature program $\left(110{ }^{\circ} \mathrm{C}(1 \mathrm{~min}), 25^{\circ} \mathrm{C} \mathrm{m^{-1 }}\right.$ to $200{ }^{\circ} \mathrm{C}(1 \mathrm{~min})$, $2{ }^{\circ} \mathrm{C} \min ^{-1}$ to $260{ }^{\circ} \mathrm{C}$ ), led to greatly improved separation and selectivity in the GC-MS/SIM detection procedure, resulting in a reproducible method with a fast run time (35 $\mathrm{min})$.
The method was applied in the analysis of a sample of Fuller's earth, obtaining a mean total PCBs concentration of $1.9 \mu \mathrm{g} \mathrm{kg}^{-1}$. There is currently no legislation in Brazil concerning PCBs in Fuller's earth, so the findings indicate the need for an environmental policy for the control of these compounds in this matrix.

\section{Acknowledgments}

The authors thank CNPq (Process: 425115/2016-0) and FAPEMIG (Fundação de Amparo à Pesquisa do Estado de Minas Gerais) for grants, fellowships, and financial support of projects that enabled the execution of this work.

\section{References}

1. Chamkasem, N.; Lee, S.; Harmon, T.; Food Chem. 2016, 192, 900

2. Mitra, S.; Sample Preparation Techniques in Analytical Chemistry, vol. 162, 1' ${ }^{\text {st }}$ ed.; Wiley: New Jersey, USA, 2003. 
3. Aota, A.; Date, Y.; Terakado, S.; Ohmura, N.; Anal. Chem. Res. 2015, 3, 13 .

4. United States Environmental Protection Agency (US EPA); PCB Inspection Manual; US EPA, Washington DC, 2004.

5. United States Environmental Protection Agency (US EPA); Persistent Organic Pollutants; US EPA, Washington DC, 2002.

6. United States Environmental Protection Agency (US EPA); A Guide to the Disposal and Decontamination of $P C B$ Contaminated Transformers and other PCB Applications; National PCB Inventory, Office of Environmental Sustainability, EPA Regional Inspectorate: Dublin, Ireland, 2012; available at https://www.epa.ie/pubs/reports/waste/haz/Disposal_ and_Decontamination_Guide_for\%20PCB-Contaminated_ Equipment_Rev1.2.pdf, accessed in September 2019.

7. Muir, D.; Sverko, E.; Anal. Bioanal. Chem. 2006, 386, 769.

8. Xu, G.; Yu, Y.; Wang, Y.; Wang, J.; Yu, R.; Chen, X.; Cui, Z.; Hum. Ecol. Risk Assess. 2018, 24, 590.

9. Wang, P.; Zhang, Q.; Wang, Y.; Wang, T.; Li, X.; Ding, L.; Anal. Chim. Acta 2010, 663, 43.

10. Silva, D. J.; Pietri, F. V.; Moraes, J. E. F.; Bazito, R. C.; Pereira, C. G.; Am. J. Anal. Chem. 2012, 3, 891.

11. United States Environmental Protection Agency (US EPA); Method 8082A: Polychlorinated Biphenyls (PCBs) by Gas Chromatography; US EPA: Washington, 2007; available at https://www.epa.gov/sites/production/files/2015-12/ documents/8082a.pdf, accessed in April 2019.

12. United States Environmental Protection Agency (US EPA); Method 8270D: Semivolatile Organic Compounds by Gas Chromatography/Mass Spectrometry (GC/MS); US EPA, Washington, 2007; available at https://19january2017snapshot. epa.gov/sites/production/files/2015-07/documents/epa-8270d. pdf, accessed in April 2019.

13. ASTM D4059 - 00: Standard Test Method for Analysis of Polychlorinated Biphenyls in Insulating Liquids by Gas Chromatography; ASTM International, West Conshohocken, PA, 2005.

14. ABNT NBR 13882: Líquidos Isolantes Elétricos - Determinação do Teor de Bifenilas Policloradas (PCB); ABNT: Rio de Janeiro, Brazil, 2008.

15. Huang, J.; Hui, Y.; Matsumura, T.; Yu, G.; Deng, S.; Yamauchi, M.; Wu, C.; Yamazaki, N.; Front. Environ. Sci. Eng. 2014, 8, 195.
16. Qi, Z.; Buekens, A.; Liu, J.; Chen, T.; Lu, S.; Li, X.; Cen, K.; Environ. Sci. Pollut. Res. 2014, 21, 6448.

17. World Health Organization (WHO); General Description Polychlorinated Biphenyls (PCBs), Air Quality Guidelines WHO, vol. 2; WHO Regional Office for Europe, Copenhagen, Denmark, 2000, p. 1-22; available at http://www.euro.who.int/_ data/assets/pdf_file/0016/123064/AQG2ndEd_5_10PCBs.PDF, accessed in January 2019.

18. Fernández, I.; Dachs, J.; Bayona, J. M.; J. Chromatogr. A 1996, $719,77$.

19. Zuloaga, O.; Etxebarria, N.; Fernández, L. A.; Madariaga, J. M.; TrAC, Trends Anal. Chem. 1998, 17, 642.

20. Anderson, J. L.; Armstrong, D. W.; Anal. Chem. 2005, 77, 6453.

21. Zhao, P.; Niu, Y.; Yu, M.; Niu, N.; Wang, H.; He, X.; Wu, B.; RSC Adv. 2015, 5, 22399.

22. Soják, L.; Pet. Coal 2004, 46, 1.

23. Harold, J. M. M.; Mcnair, M.; Basic Gas Chromatography, $1^{\text {st }}$ ed.; Wiley: New Jersey, USA, 2009.

24. United States Environmental Protection Agency (US EPA); Method 3550C: Ultrasonic Extraction; US EPA, Washington, 2007; available at https://19january2017snapshot.epa.gov/sites/ production/files/2015-12/documents/3550c.pdf, accessed in September 2019

25. Ayris, S.; Currado, G. M.; Smith, D.; Harrad, S.; Chemosphere 1997, 35, 905.

26. Statistica 6.0; StatSoft, Tulsa, OK, USA, 2009.

27. Huber, P. J.; Ann. Math. Stat. 1965, 36, 1753.

28. Ribani, M.; Beatriz, C.; Bottoli, G.; Collins, C. H.; Sales, C.; Jardim, F.; Melo, L. F. C.; Quim. Nova 2004, 27, 771.

29. Ballschmiter, K.; Ellinger, S.; Hackenberg, R.; Environ. Sci. Technol. 2004, 38, 2288.

30. Zhang, M.; Kruse, N. A.; Bowman, J. R.; Jackson, G. P.; Appl. Spectrosc. 2016, 70, 785.

31. Halfadji, A.; Touabet, A.; Green Chem. Lett. Rev. 2018, 11, 209.

32. Koo, I.; Kim, S.; Zhang, X.; J. Chromatogr. A 2013, 1298, 132.

33. Melnyk, A.; Dettlaff, A.; Kuklińska, K.; Namieśnik, J.; Wolska, L.; Sci. Total Environ. 2015, 530, 18.

Submitted: March 28, 2019

Published online: September 23, 2019 